\title{
シンポジゥム $(\mathbf{1})$ 気管支喘息の薬物評価法
}

\section{吸入療法の現状と問題点}

\section{1. ぜんそくとは？}

ぜんそくとは「広範な気管支の狭窄による疾患で，そ の強さが自然に，あるいは治療によつて短時間で変化 し，かつ心臟血管系疾患に原因しないもの」と定義され ている，簡単にいえば，閉塞性障害で reversible なも のといらわけ，閉塞性障害は気道抵抗，呼吸抵抗あるい は 1 秒量， 1 秒率を指標とすればよいが，reversibleな ので薬物療法の評価が困難である. ぜんそくの薬物療法 の評価には，つぎのような基本的な問題点が存在する.

(i) 症状の自然的改善

(ii) 季節的要因, 時間的要因

（iii） 検查のやり方, 測定の方法, 患者の協力

(iv) 対象とする群の構成, ぜんそくの種類

したがって，ぜんそくの内服薬の評価はきわめて困難 であるが，吸入薬ならば評価は比較的楽である.

\section{2. 気管支拡張剤吸入による可逆性テスト}

気管支拡張剤を吸入させて，その前後の閉塞性障害の 程度を比べればよい，例えば，1秒量を指標とすれば， その薬剤による改善率はつぎのように示される.

改善率 $=\frac{\text { 吸入後の } 1 \text { 秒量一吸入前の } 1 \text { 秒量 }}{\text { 吸入前の } 1 \text { 秒量 }} \times 100(\%)$ この改善率は,つぎのように判定される.

改善率 $4 \%$ 以下……改善しない (-)

$$
\begin{aligned}
& 5 \sim 19 \% \cdots \cdots \text { やや改善（士） } \\
& 20 \sim 49 \% \cdots \cdots \text { 改善 }(+) \\
& 50 \% \text { 以上...著明な改善（H） }
\end{aligned}
$$

ぜんそくでは，少なくも20\%以上の改善を認めるもの で，20\%以上の改善を認めないときは肺気腫を考えねば ならない。

しかし，気管支拡張剤は正常の気管支を拡げるのを目

* 名古屋保健衛生大学医学部内科
的としない，れん縮をおこしている気管支を拡げるのが 目的で, bronchodilator というより broncho-spasmolytic agent というべきだ。 とすれば spasmogen を与 えてから吸入させて効果をみるのがよい，さらに，あら かじめ気管支拡張剤を投与し，そのあとで spasmogen を吸入させて，気管支抎張剂を投与していない control との差をみれば，ぜんそく阻止率を出すこともできる． control $\rightarrow$ spasmogen (control fall) bronchodilater $\rightarrow$ spasmogen (test fall) $\%$ protection $=\frac{\text { control fall-test fall }}{\text { control fall }} \times 100$ なお， spasmogen としては,

i) chemical mediator $\cdots$ acetylcholine, histamine

ii) antigen $\cdots$ in sensitized patients

が用いられる。しかし，これらを吸入して本当のぜんそ く発作を抢こしては困る．スパイロで努力性呼出曲線の 変化をみて判定するのであるが，有効な気管支拡張剤エ ロゾルと $\mathrm{O}_{2}$ をフラッシュする準備が必要である（図 1).

この回路を利用して吸入アレルゲンの減感作もできる し, 大気污染地区の污染物質とぜんそくの因果関係の追 求もできると思う.

\section{3. ぜんそくの薬}

吸入療法として使われているぜんそくの薬は, 主とし て気管支拡張剂, 粘液溶解剂および加湿剂, つまり気道 よりの水の補給の 3 つであろう.

\section{(1) 気管支拡張剤}

交感神経刺激剤とキサンチン誘導体が使われ，この作 用機序は dynamic receptor theory で説明される（図 $2)$.

交感神経刺激剂はカテコールアミンで，これが細胞膜 につくと adenylcyclase を活性化する. 活性化した 


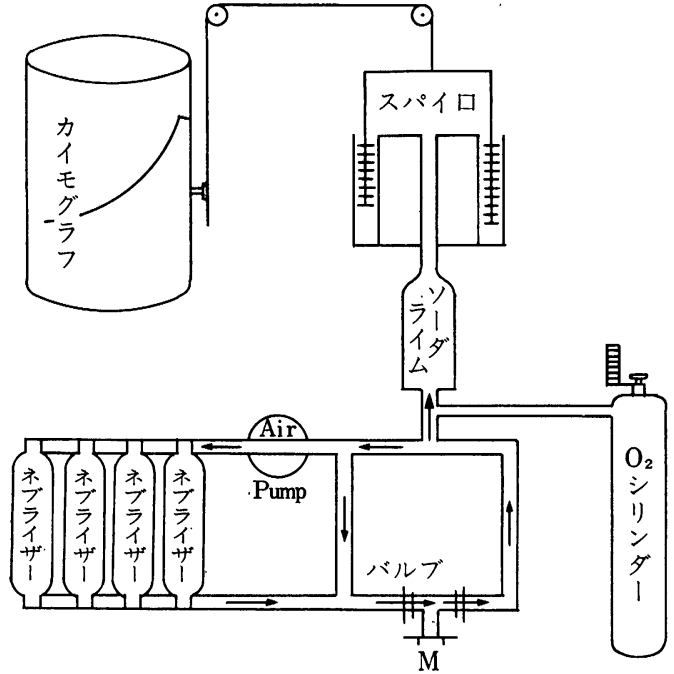

図 1 吸入試験の回路

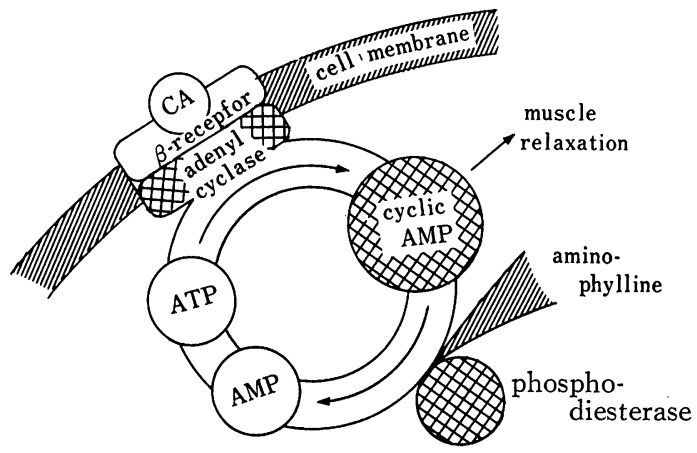

図 2 Dynamic receptor theory

adenylcyclase は ATP cyclic AMP にかえる。こ の cyclic AMP が $\beta$ 作用の本体で，平滑筋を号緩させ るが，一方心筋のトーヌスを増し，解糖作用もある. し かし， cyclic AMP は phosphodiesterase といら酵素 によって不活性化し，AMP となる。こうなると $\beta$ 作 用は消失して失う。この phosphodiesterase を阻止し, $\beta$ 作用を長もちさせるのがキサンチン誘導体だという. こう薬の作用を考えれば，気管支拡張作用をねらつても 使い方が悪いと，どうきがしたり心筋の障害もおこしが ちとなることが当然となる．副作用といらより薬剮本来 の作用で，ぜんそくの薬としては使い方が問題となつて くる.

（2）喀痰溶解剂

たんと一ロにいっても，その成分には差があると思わ れる. ぜんそくのたんは，軽症のばあいでも粘調なのが
特長である. そして, 水分とともに多糖類, 蛋白質など を含んでいる，喀痰溶解剂は，それぞれのたんの成分に みあって作用し: ciliary escalationをうまく働かせる ものであつてほしい. 近ごろ多く使われている薬は, シ ステイン系薬剤，ビソルボンおよび各種の消炎酵素剤で ある.

\section{（3）水の補給}

ぜんそく発作があると, 攝食, 飲み水の減少となる. さらに努力呼吸のため発汗量は増加し，気道よりの不感 性水分の哀失が增大する．このためにいろいろな脱水症 状が現われるし，たんの粘調度はますます增大して咳嗽 不全をおこし，呼吸不全におち入る危険が大きくなる. したがつて，ぜんそくでは水分の補給が必要で，経血管 で $5 \%$ ブドウ糖液を 1000 $1500 \mathrm{ml}$ 点摘投与するが，吸 入でも加湿剂が大切である.

これらのほかに，適応を選んで抗生物質や割腎皮質ス テロイドの吸入を行うこともある.

吸入用薬剤をまとめると，つぎのと扤りである.

1) 清浄剤 detergents 加湿剂 wetting agents

2）気管支拡張剤 bronchodilator

3）喀たん溶解剤 pus liquifying agents, secretionthinning substances, mucolytic agents.

4) 抗生物質 antibiotics

5）副腎皮質ステロイド

私はこれら 吸入薬を, 抗結核薬のばあいになぞらえ

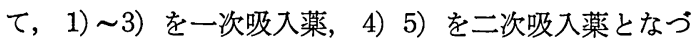
けている.

\section{4. エロゾル粒子と気道沈着部位}

吸入する薬剤はその粒子の大きさによつて, 気道内の 沈着部位が違う。 $60 \mu$ 以上の粒子はほとんど気管粘膜に 沈着する. そして第一次気管支には $2 \mu$ 以下の粒子は沈 着しない.

第二次気管支からは， $2 \mu$ の粒子が沈着しはじめる. そして，20 $\mu$ 以上の粒子は呼吸細気管支には到達しな い. $1 \mu$ 以下の粒子は肺胞にまで入るけれども, 呼気で 排出されて失う。このように粒子の大きさによつて気道 内の分布, 沈着の様相が違らので, 目的によつて粒子を 変えるべきである.一般に吸入療法は，つぎのように区 分される.

(i) humidifier

(ii) vaporizer

(iii) atomizer 
(iv) nebulizer

もつとも粒子の大きいのは蒸気であるが, 吸入する道 具だてが違うのである.、かに有効な薬でも吸入用の道 具が違えば有効でなくなる，ぜんそくのばあいは，かな り細かい粒子も必要とするが，ぜんそくのばあいの気管 支筋のれん縮はかなり太い部位から細気管支まで広範に おこるようである.したがつて，吸入するエロゾル粒子 恃あまり均一でない活らが良いということになる、一般 的には $1 \sim 3 \mu$ のエロゾル粒子を多数発生する日商式ネ ブライザーが広く使われている。

\section{Ultrasonic nebulizer}

放射性エロゾルを普通のネブライザーで吸入させて肺 スキヤンを行なうと喉頭, 気管が造影されるのみである が，超音波ネブライザーを使うと肺の全体像がとらえら れる.これは超音波ネブライザーだと $1 \mu$ 前後の細かな 粒子となり，また均等性の粒子となるためである. 人間 の肺は，正常でも吸気が均等に分布するわけではない。

病的な肺では, この不均等性はさらに著明となる.しか も, 吸入薬を十分に到達させたい部位は, 吸気のもつと も入り難い部位である.このために, 目的部位に達しな い薬は, 上気道などの粘膜から吸収され，薬の種類によ つては血流を增やし, 病変部位の換気血流比をさらに小 さくして，低 $\mathrm{O}_{2}$ 血症をひどくする. この立場からすれ ば，細かく均等なエロゾルを発生する超音波ネブライザ 一が良いということになる。

\section{6. 压呼吸による吸入}

吸気の肺内分布不均等性のひどいときは，超音波ネブ ライザーを圧呼吸器に組み合わせるのがよい，広く使わ れている圧呼吸器は, バードタイプか, ベネットタイプ で, 吸入のやり方は吸気時にのみ圧のかかる間けつ的陽 圧呼吸, IPPB/Insp. である. 加圧してエロゾル吸入を させると，たんを押し込みはしないかと考えがちである が，そうではない，加圧によるたん排出機構は長野氏が うまく説明している(図3)。うすいたんは，圧がかかる と两壁に抎しやられ，線毛作用で排出される。こいたん は線毛作用だけではうまく出ない，このばあいは肺胞内 圧を高め，せきを有効にさせてたんを出す．このとき colateral respiration が役に立つ.

\section{Spray の問題点}

最近, ぜんそく吸入薬として市販されているスプレー にいろいろと批判が高まり，要指示薬となつた，ぜんそ

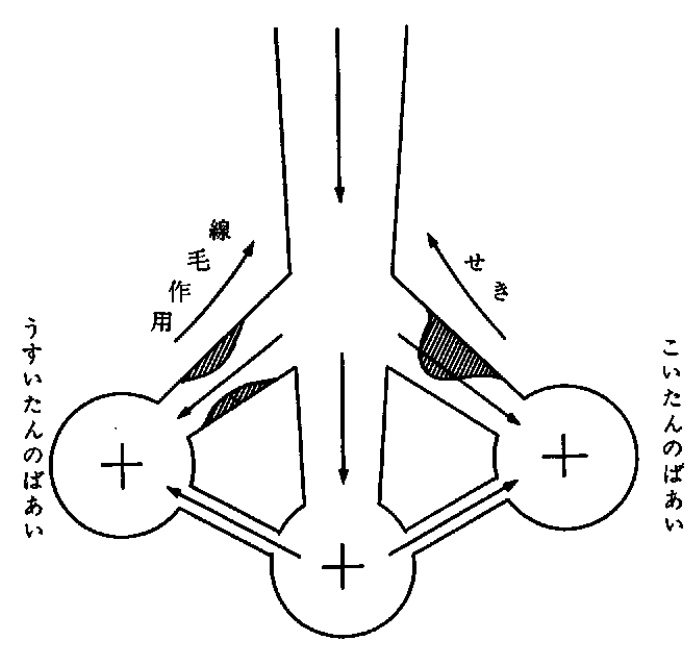

图 3 加圧による痰排出機構

くという病気は大変に苦しいので，とかく量が增えがち である．量が多いと $\beta$ 作用として循環系への影響も出 て具合が㤠い，また，スプレーで薬をとぱすのにフレ ホンガスを使つているので，その影響む考えねばならな い. しかし，救急処置としてスプレーの役割は大切だと 思う. 問題は適切な使い方を指導することにある. スプ レーでは薬郕の粒子はかなり大きい，とても細気管支に 沈沈着しないと思う。しかし，ぜんめいは消えるもので ある、これは，ぜんそくのばあいの気管支のれん縮は，

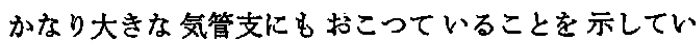
る.つまり，スプレーも有効なのであるが，粒子が大き ければ口腔にも沈着しがちである。これを飲みこんでは むちろんいけないが，飲みこまなくても口腔粘膜は薬 剂の吸収能が高いものである. したがつて，吸入したあ とうがいをさせるべきであるう，下手に使用すると，交 感神経刺激薬が循環面に作用し，心拍出量を増し，換気 血流比 (VA/Q) が小さくなる.このために吸入すると， かえつて低 $\mathrm{O}_{2}$ 血症がおこるといら矛盾を生ずる．吸入 療法というのは粘膜の局所に作用させるべきもので，で きるだけ吸収しないよう使うべきである.この点, 粘膜 から吸収しない薬剤の開発が望まれる。

\section{8. むすび}

吸入療法の有効性は, 吸入薬風の選択, 投与量と投与 回数だけでなく，ネブライザーの性能と選択，および吸 入のやり方に大きく左右される。したがつて，薬剤の有 効性を評価するには，これらの因子を十分に考感しなけ 
ればならない，なお，ぜんそくの薬物寮法といっても， ぜんそくの原因が数多くあり, 決して単一のものではな い. 感染性ぜんそくでは抗生物質が, アレルギー性のぜ んそくは減感作用療法が基本的な治療であろう。ここに 述べた気管支拉張剤や粘液溶解剂は，原因のいかんを問 わず使われる対症的なものである.つまり，気管支拡張 㓮はぜんそくの薬というよりも閉塞性障害の薬である. そして，閉塞性障害に対する気管支拡張剤内服の効果を 評価するにはぜんそく症例はうまくない，常時，多少な りとも閉塞性障害を有する慢性気管支炎やじん肺症を対
象とするのがよいと考える．ぜんそくは日時変化がはげ しく, 検查時期あるいは検查時間によつて差が大きいか らである. そして，ぜんそくは可逆性の大きい閉塞性障 害なのだから，閉塞性障害に有効な気管支拉張剤はもち ろん有効な山ずである。ぜんそく薬の評価は，一年のす べての季節をとおして蹦床家がキメ細かに観察した衣見 がむのをいうと思う．1秒量や1秒率の数字ではなく， 発作がどうなったか，たんは出やすくなつたかどらか， というような臨休所見に 重きをおきたいと思うのであ る. 